\title{
ELEMENT COMPOSITION OF TRACHELOMONAS ENVELOPES (EUGLENOPHYTA)
}

\author{
Malgorzata PoniewoziK
}

\begin{abstract}
Cells of euglenoid Trachelomonas Ehrenb. vary in the size, shape and appearance of the external envelope's ornamentation, as well as internal structure. The loricae are generally similar in color, ranging from light (hyaline, yellowish, golden, reddish, brownish) to dark (brown, black). This study examined the loricae of twelve trachelomonad species, some light (yellow to golden) and some dark (brown). There were no black loricae, suggesting that little or no Mn was taken up by the cells. Though the envelopes differed in surface ornamentation and color, comparative SEM-EDS analyses of all the material studied showed high iron content, silicon mineralization, and no manganese. The degree of iron and silicon mineralization varied. Some loricae had high silicon content (e.g., T. compacta Middelhoeck) and others were more saturated by iron ions (T. manginii Deflandre, T. lacustris Drezep.).
\end{abstract}

Key words: element composition, euglenoids, loricae, SEM, Trachelomonas, X-ray analysis

Matgorzata Poniewozik, Department of Phycology, W. Szafer Institute of Botany, Polish Academy of Sciences, Lubicz 46, $31-512$ Kraków, Poland; e-mail: m.poniewozik@botany.pl

\section{INTRODUCTION}

The euglenophytes are a heterogeneous group of freshwater and marine flagellates. Some of them are naked, covered only by the periplast (e.g., the genera Euglena Ehrenb., Phacus Dujard., Astasia Ehrenb.), and others (Trachelomonas Ehrenb., Strombomonas Deflandre, Ascoglena F. Stein) have an external lorica (envelope) which encloses the cell. The envelopes of euglenophytes, built of mucopolysaccharides and initially flexible, become mineralized by mineral salts and turn into solid structures (Leedale 1975; Conforti et al. 1994). Envelopes in this form are used for taxonomic identification. That manner of identification was initiated by Ehrenberg in the $19^{\text {th }}$ century (Ehrenberg 1833). A hundred years later, Deflandre defined a new loricated genus, Strombomonas (Deflandre 1930). In later studies of lorica structure and its formation process, Brosnan et al. (2005) maintained Strombomonas and Trachelomonas as separate genera. At present, some cytological characteristics, in addition to cell size, are used for taxonomic diagnoses. The number and shape of chloroplasts as well as the presence and structure of pyrenoids are most important, but the principal criteria are still the appearance of loricae - their shape, the presence or lack of a collar or thickening around the apical pore, and external structure. In Trachelomonas the envelope surface presents great diversity. Many studies have employed scanning electron microscopy to explore the external structure of envelopes in detail (e.g., Leedale 1975; West \& Walne 1980; Dunlap et al. 1983; Conforti et al. 1994; Wang et al. 2000; Pereira \& Azeiteiro 2003; Pereira et al. 2003; Wołowski \& Hindák 2004; Wołowski \& Walne 2007; Duangjan \& Wołowski 2013; Poniewozik 2016; Wołowski et al. 2016). The shape and appearance of loricae are characteristic features of species but the chemical composition and proportions of individual elements of the envelope wall may vary to some extent. Despite all the research on trachelomonad loricae, there is still relatively little information on the chemical composition of their envelopes. The main elements that build the envelope include iron ( $\mathrm{Fe}$ ) and manganese (Mn). An increase of $\mathrm{Fe}$ or $\mathrm{Mn}$ in the environment can alter 
the microarchitecture of loricae, increasing the number of granular formations or spicules (Dunlap \& Walne 1987). Carbon, oxygen and nitrogen are usually in great abundance; other constituents of loricae are $\mathrm{Si}, \mathrm{P}, \mathrm{S}, \mathrm{K}, \mathrm{Mg}, \mathrm{Al}$ and $\mathrm{Cl}$ (West et al. 1980; Dunlap et al. 1986). Some minerals (e.g., $\mathrm{Ti}, \mathrm{Ba}, \mathrm{Ni}, \mathrm{Cu}, \mathrm{Pb}, \mathrm{Mo}$ ) occur in lesser amounts (Mann \& Fyfe 1988).

In this study I examined the chemical composition of Trachelomonas envelopes, using loricae from field samples. An aim of this work was to determine whether loricae differing in wall surface (smooth, spiny, warty) also differed in chemical composition.

\section{MATERIALS AND METHODS}

Samples were netted ( $20 \mu \mathrm{m}$ mesh) from two natural freshwater bodies near each other in eastern Poland: Nadrybie Reservoir $\left(51^{\circ} 20^{\prime} \mathrm{N}, 23^{\circ} 3^{\prime} \mathrm{E}\right)$ and a small abandoned clay-pit $\left(51^{\circ} 22^{\prime} \mathrm{N}, 23^{\circ} 1^{\prime} \mathrm{E}\right)$. Both waterbodies had densely overgrown shores and were rich in organic matter. The organisms were analyzed and identified, first by light microscopy (Nikon Eclipse E600, Nomarski differential interference contrast) and then by scanning electron microscopy. All LM observations were of living material. Taxonomic identification followed Starmach (1983), Wołowski and Hindák (2005) and Dillard (2000). Material for further analyses was fixed with glutaraldehyde/formaldehyde. Samples for SEM were prepared as described by Bozzola and Russel (1995). The fixed material was washed several times in distilled water to remove buffer salts and then dehydrated in a graded ethanol series. Then drops of dehydrated material were transferred on slides mounted on aluminum stubs (Ø $10.0 \mathrm{~mm})$ with graphite paint and air-dried overnight at $c a 20^{\circ} \mathrm{C}$. After drying, the stubs were coated with a $20 \mathrm{~nm}$ carbon layer using a Cressington sputter-coater. SEM observations of carbon-coated material employed a Hitachi S-4700 microscope (Laboratory of Field Emission Scanning Electron Microscopy and Microanalysis, Jagiellonian University, Kraków, Poland). Element composition was microanalyzed with the same unit operating at 20 $\mathrm{keV}$ and equipped with an X-ray detector (ThermoNORAN Vantage energy-dispersive spectrometer). The
$\mathrm{X}$-ray spectra were generated over $50 \mathrm{~s}$ life-times from 0 to $15 \mathrm{keV}$ and with a take-off angle of $30^{\circ}$.

\section{RESULTS}

In this study the ultrastructure and chemical composition of Trachelomonas loricae of selected species were analyzed in a number of taxa. Five were species with smooth loricae: the slightly oval loricae of Trachelomonas volvocina Ehrenb. var. volvocina (Fig. 1), the consistently round loricae of $T$. volvocinopsis Svirenko fo. volvocinopsis (Fig. 2), and the transverse oval loricae of T. curta A. M. Cunha fo. curta (Fig. 3), T. dubia Svirenko emend. Deflandre (Fig. 4) and T. manginii Deflandre (Fig. 5). The loricae of T. dubia and T. curta were the palest (yellowish to golden), and those of $T$. volvocina and $T$. volvocinopsis were reddish to brownish. The next group consisted of five spiny loricae: T. hispida (Perty) F. Stein var. hispida (Fig. 6), T. caudata (Ehrenb.) F. Stein fo. caudata (Fig. 7), T. cf. hirta A. M. Cunha var. duplex Deflandre (Fig. 8), T. lacustris Drezep. (Fig. 9) and T. verrucosa A. Stokes var. granulosa (Playfair) W. Conrad (Fig. 10). The latter had short, thick, blunt spines, and the rest had fairly narrow, sharp spines. T. caudata had the darkest loricae; they were brown, not black or blackish. Also studied was $T$. compacta Middelhoeck (Fig. 11), having small depressions on the lorica wall surface, and T. intermedia P. A. Dangeard (Fig. 12), having small pores on a smooth surface.

SEM-EDS analyses showed that all the examined loricae were of generally similar composition. The main components were silicon and iron (Table 1). The analysis did not indicate the presence of manganese in any of the studied envelopes.

The external surfaces of the studied Trachelomonas volvocina var. volvocina, $T$. volvocinopsis fo. volvocinopsis, T. curta fo. curta and T. dubia were all smooth, without any external structures or processes, but energy-dispersive X-ray analysis showed differences in the content of basic

Figs 1-8. External views of the studied loricae. 1 - Trachelomonas volvocina Ehrenb. var. volvocina, 2 - T. volvocinopsis Svirenko fo. volvocinopsis, 3 - T. curta A. M. Cunha fo. curta, 4 - T. dubia Svirenko, 5 - T. manginii Deflandre, 6 - T. hispida (Perty) F. Stein var. hispida, $7-$ T. caudata (Ehrenb.) F. Stein fo. caudata, $8-T$. cf. hirta var. duplex Deflandre. 

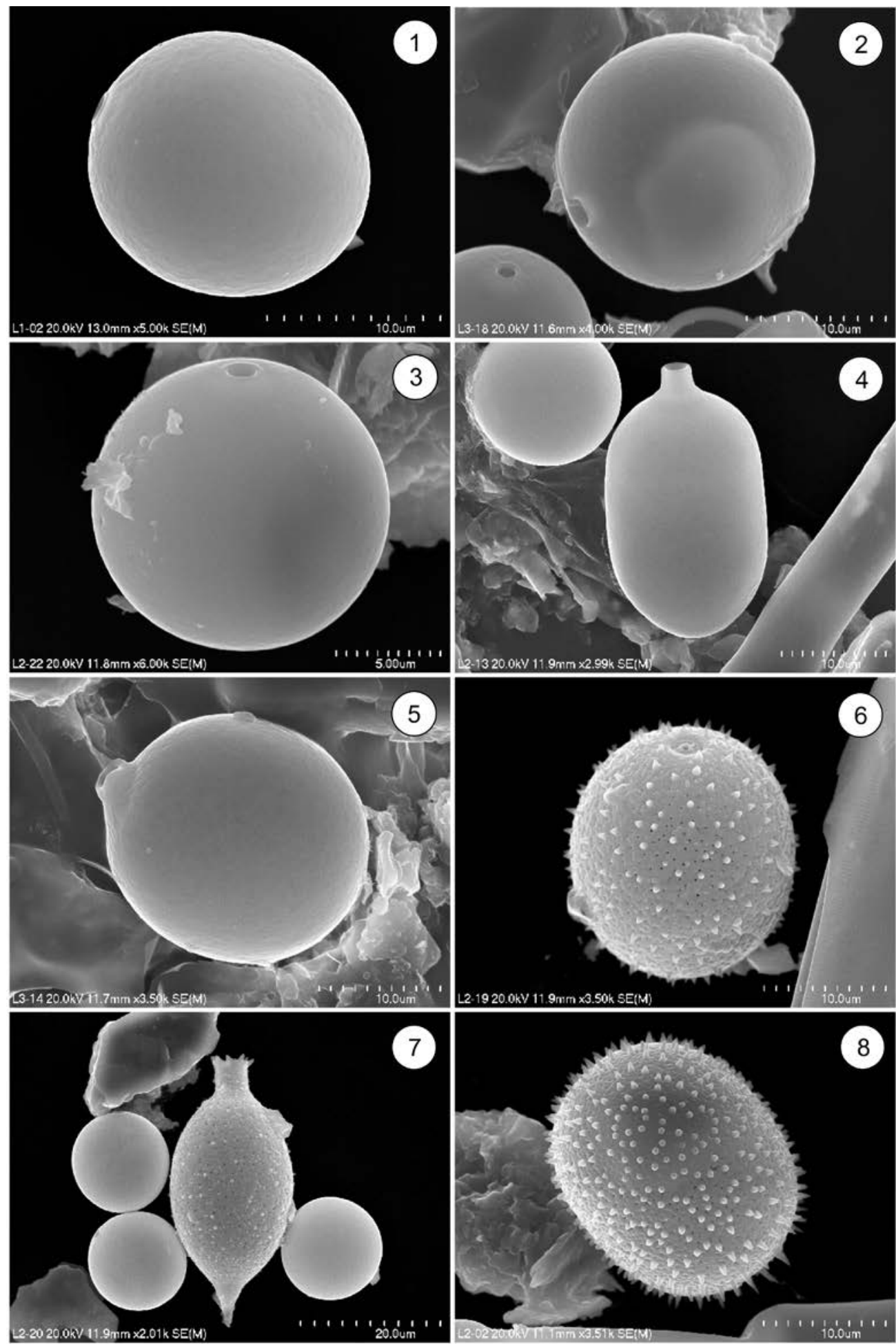
Table 1. Relative amounts of the main elements in envelopes of the studied trachelomonads. 0 - EDS analysis of basal glass, 1 - Trachelomonas volvocina Ehrenb. var. volvocina, 2 - T. volvocinopsis Svirenko fo. volvocinopsis, 3 - T. curta A. M. Cunha fo. curta, 4 - T. dubia Svirenko, 5 - T. manginii Deflandre, 6 - T. hispida (Perty) F. Stein var. hispida, 7 - T. caudata (Ehrenb.) F. Stein fo. caudata, 8 - T. cf. hirta var. duplex Deflandre, 9 - T. lacustris Drezep., 10 - T. verrucosa A. Stokes var. granulosa (Playfair) W. Conrad, $11-T$. compacta Middelhoeck, $12-T$. intermedia P. A. Dangeard.

\begin{tabular}{|c|c|c|c|c|c|c|c|c|c|c|c|c|}
\hline & \multicolumn{2}{|c|}{$\mathrm{Al}$} & \multicolumn{2}{|c|}{$\mathrm{Si}$} & \multicolumn{2}{|c|}{$P$} & \multicolumn{2}{|c|}{$\mathrm{K}$} & \multicolumn{2}{|c|}{$\mathrm{Fe}$} & \multicolumn{2}{|c|}{$\mathrm{Na}$} \\
\hline & $\begin{array}{c}\text { Atom } \\
{[\%]}\end{array}$ & $\begin{array}{c}\text { Err. }+/- \\
{[\%]}\end{array}$ & $\begin{array}{c}\text { Atom } \\
{[\%]}\end{array}$ & $\begin{array}{c}\text { Err. }+/- \\
{[\%]}\end{array}$ & $\begin{array}{c}\text { Atom } \\
{[\%]}\end{array}$ & $\begin{array}{c}\text { Err. }+/- \\
{[\%]}\end{array}$ & $\begin{array}{c}\text { Atom } \\
{[\%]}\end{array}$ & $\begin{array}{c}\text { Err. }+/- \\
{[\%]}\end{array}$ & $\begin{array}{c}\text { Atom } \\
{[\%]}\end{array}$ & $\begin{array}{c}\text { Err. }+/- \\
{[\%]}\end{array}$ & $\begin{array}{c}\text { Atom } \\
{[\%]}\end{array}$ & $\begin{array}{c}\text { Err.+/- } \\
{[\%]}\end{array}$ \\
\hline 0 & 4.63 & 0.19 & 67.65 & 0.36 & - & - & 8.70 & 0.23 & - & - & 10.47 & 0.17 \\
\hline 1 & 3.06 & 0.10 & 31.04 & 0.27 & 13.51 & 0.15 & 3.32 & 0.15 & 29.59 & 0.50 & 12.99 & 0.32 \\
\hline 2 & 3.73 & 0.18 & 49.81 & 0.50 & 8.10 & 0.25 & 7.23 & 0.34 & 11.09 & 0.43 & 7.29 & 0.43 \\
\hline 3 & 6.38 & 0.18 & 37.26 & 0.46 & 15.73 & 0.46 & 3.47 & 0.12 & 23.41 & 0.69 & 6.58 & 0.45 \\
\hline 4 & 3.36 & 0.18 & 26.74 & 0.46 & 18.62 & 0.49 & 3.31 & 0.13 & 36.63 & 0.90 & 2.75 & 0.50 \\
\hline 5 & 2.48 & 0.26 & 13.74 & 0.33 & 28.96 & 0.69 & 0.94 & 0.17 & 41.63 & 1.20 & 3.63 & 0.46 \\
\hline 6 & 4.04 & 0.14 & 43.22 & 0.49 & 12.34 & 0.48 & 4.96 & 0.28 & 17.33 & 0.70 & 12.01 & 0.23 \\
\hline 7 & 2.73 & 0.17 & 39.23 & 0.53 & 11.47 & 0.50 & 8.06 & 0.41 & 20.53 & 0.97 & 8.16 & 0.25 \\
\hline 8 & 3.98 & 0.15 & 29.7 & 0.24 & 17.12 & 0.24 & 3.28 & 0.26 & 27.2 & 0.79 & 9.16 & 0.25 \\
\hline 9 & 6.51 & 0.25 & 21.73 & 0.30 & 18.09 & 0.32 & - & - & 39.75 & 1.27 & 2.83 & 0.46 \\
\hline 10 & 5.81 & 0.34 & 34.88 & 0.47 & 17.22 & 0.25 & 2.76 & 0.23 & 26.08 & 0.68 & 5.55 & 0.22 \\
\hline 11 & 13.39 & 0.17 & 73.56 & 0.54 & - & - & 3.58 & 0.29 & 4.07 & 0.53 & - & - \\
\hline 12 & 5.14 & 0.09 & 56.99 & 0.30 & 4.02 & 0.12 & 7.05 & 0.18 & 9.18 & 0.37 & 11.46 & 0.21 \\
\hline
\end{tabular}

components of these envelopes (Table 1). The loricae of $T$. dubia had comparable amounts of silicon and iron and were slightly mineralized. $\mathrm{Si}$ was the main mineralizing element in the other three species; Fe was present in smaller amounts, least in $T$. volvocinopsis (Table 1). In the lorica of T. manginii, phosphorus (P) was an important chemical component in addition to the $\mathrm{Si}$ and Fe (Table 1).

In the group of trachelomonads represented by $T$. hispida var. hispida, T. caudata fo. caudata and T. verrucosa var. granulosa, the envelope wall was fairly rough and covered with spines or granules. EDS showed Si to be a very important element in these species. Fe usually occurred in smaller amounts. In addition to silicon and iron, the spines covering the loricae of $T$. cf. hirta var. duplex and T. lacustris also contained a large amount of phosphorus (Table 1). The lorica of $T$. compacta, which showed scrobiculate external structure, was composed mainly of silicon compounds, with negligible content of the other elements (Table 1). The lorica of $T$. intermedia was very strongly mineralized by $\mathrm{Si}$, with smaller amounts of the remaining elements (Table 1). The high amounts of carbon (C) in the initial dataset are ignored because the SEM samples were carboncoated. Carbon is known to be a component of loricae but in this analysis it was not possible to factor out the amount of carbon in the coating.

\section{Discussion}

These analyses indicated that, apart from iron, silicon was the main component of the wall in all loricae. Previous studies have detected Si in the chemical composition of envelopes (West 1977; Donnelly 1979; West et al. 1980) but noted it as an accompanying element. Later, Steinberg and Klee (1984) showed silicon to be the main element in the loricae of some trachelomonad species, (e.g., T. volvocina, T. hispida, T. hispida var. punctata Lemmerm), accompanied by smaller amounts of $\mathrm{Fe}, \mathrm{Ca}, \mathrm{Cu}, \mathrm{Zn}$ and even $\mathrm{Co}$; $\mathrm{Si}$ was the only element they found in the loricae of T. rasumowskoensis Dolgoff. Si was the only element I detected in $T$. compacta loricae. It should be mentioned that the $T$. rasumowskoensis specimens Steinberg and Klee (1984) studied probably were chrysophycean cysts, not the trachelomonad representative. Wołowski (2005) discussed the taxonomic position of that species, suggesting it to be a chrysophyte 

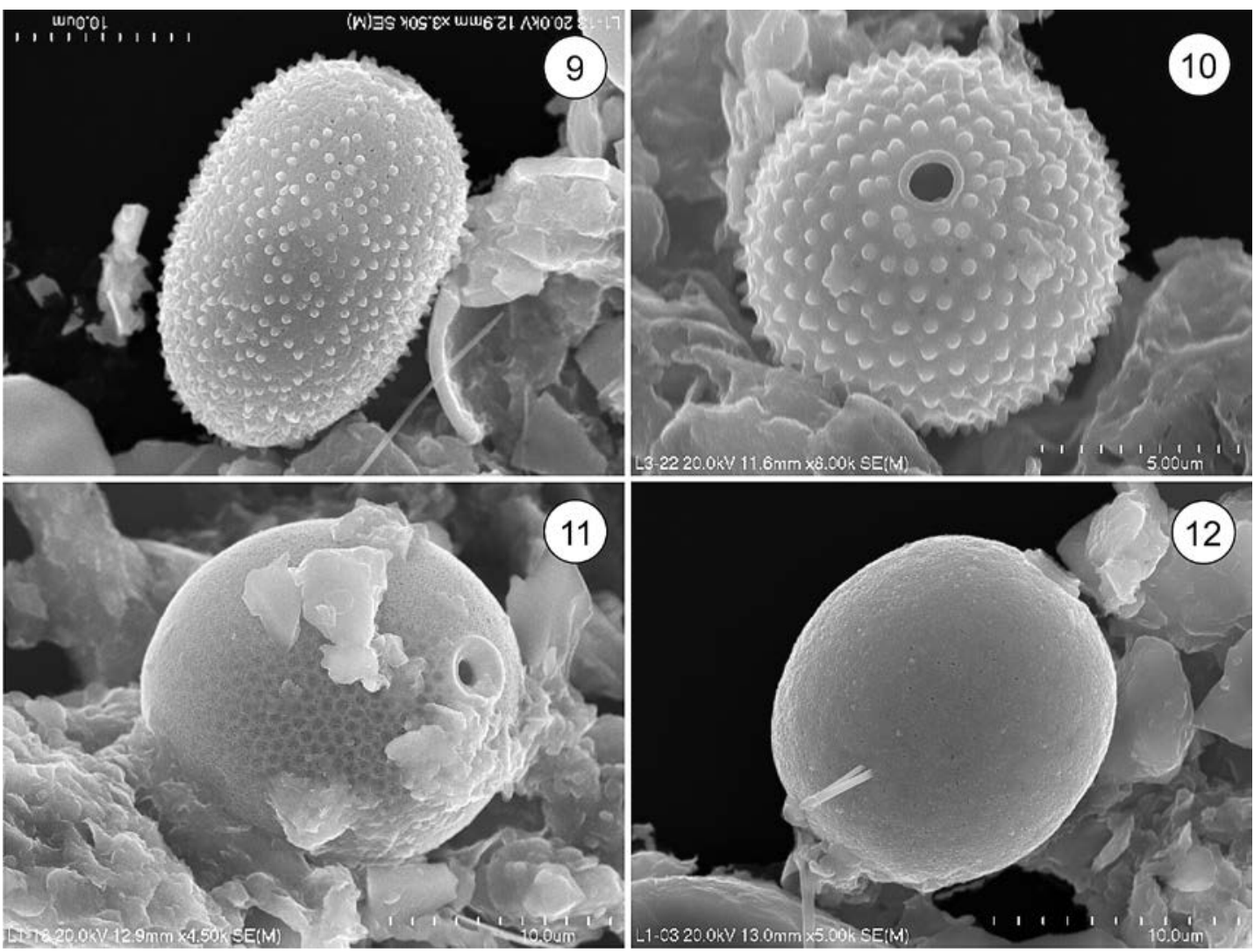

Figs 9-12. External views of the studied loricae. 9 - Trachelomonas lacustris Drezep., 10 - T. verrucosa A. Stokes var. granulosa (Playfair) W. Conrad, 11 - T. compacta Middelhoeck, 12 - T. intermedia P. A. Dangeard.

cyst. Wang et al. (2003) reported high Si content in several loricae of Trachelomonas; they found $\mathrm{Si}$ in all the loricae they studied, but it dominated in those that had a rough surface (T. scabra Playfair, T. silvatica Svirenko); smooth loricae (T. volvocina) had high amounts of iron, with Si also occurring in significant amounts. Barnes et al. (1986) found small amounts of Si occurring in granular regions along the margins of $T$. lefevrei Deflandre envelopes, Fe being the major element (Barnes et al. 1986). Possibly some of the silicon in the loricae I analyzed came from the cover slips used for preparing the material, but other work on similar trachelomonad taxa has shown silicon to be a component of the lorica, along with iron and/or manganese (Poniewozik 2015; Wołowski et al. 2016). In Strombomonas, Conforti et al. (1994) found Si to be the main component of loricae, with much lower Fe content and a trace amount of $\mathrm{Mn}$; they attributed their findings to the specific structure of Strombomonas loricae, which were rough on the surface and had accumulated extraneous particles, including sand grains. In my study, smooth as well as rough loricae of Trachelomonas were saturated with silicon. According to Wang et al. (2003), the Si in Strombomonas loricae comes from exogenous particles like sand grains but is also evenly distributed in envelopes of Strombomonas and Trachelomonas and is a constitutive element of the envelope. The high amount of silicon in loricae might be explained in part by the possibility that the brown compounds of the trachelomonad loricae are iron silicates or phosphosilicates of iron or manganese (Pereira \& Azeiteiro 2003). Steinberg and Klee (1984) suggested that the large amount of Si in trachelomonad 
loricae indicates that the formation of loricae impregnated with inorganic compounds starts with a silicification process, and may be a common process in organisms of different taxonomic groups that produce external structures. Silicon is well known as the main component in diatoms and chrysophyte stomatocysts, but also in chlorophytes, haptophytes and dinoflagellates (Preisig 1994; Pla 2001). In my study, I found that iron usually occurred in considerable amounts, in addition to silicon. Conforti et al. (1994) found that the loricae of T. volvocina and T. similis A. Stokes consisted mainly of iron, with Si present in small amounts. In Trachelomonas lefevrei loricae, Fe as well as Mn were detected, in varying proportions depending on the color and age of the cells (Dunlap et al. 1983). Manganese was not present in the envelopes of any of the loricae I studied. This is surprising, because smaller or larger amounts of Mn have usually been found in other work on the chemical composition of envelopes (Dunlap et al. 1983; 1986; Barnes et al. 1986; Pereira et al. 2003). Only Wang et al. (2000, 2003) detected no manganese in loricae. Among the heavy metals, $\mathrm{Mn}$ is known to be an essential micronutrient for plant organisms, required for redox reactions as an enzyme cofactor and for protection against oxidative stress (Bowler et al. 1994; Büchel et al. 1999). The acquisition of this metal is based on active transport. The uptake of manganese is determined by cell activity (Dunlap et al. 1983) and, as in the case of other ions, is affected by $\mathrm{pH}$ and other environmental conditions. Richardson et al. (1988) reported that manganese oxidation occurred in a dense population of phytoplankton that generated microenvironment conditions exceeding pH 9. In experiments by Ferroni et al. (2004), the X-ray emission peak corresponding to Mn did not differ between Euglena gracilis G. A. Klebs cells exposed to manganese excess and control cells, even though the internal concentration of $\mathrm{Mn}$ was two times higher in the Mn-exposed cells. They attributed this finding to the presence of $\mathrm{Mn}$ in diluted form throughout the cells, not detectable by the X-ray method. Pereira et al. (2003) found that $T$. hispida var. coronata Lemmerm. loricae contained a large amount of $\mathrm{Fe}$ and no manganese, despite the high amount of dissolved manganese recorded in the water, which was half the amount of dissolved Fe recorded. Phytoplankton cells take up and accumulate manganese (II) intracellularly (Sunda \& Huntsman 1986), and in some cases this may explain why manganese ions were not detected. The lack of manganese in the chemical composition of loricae might also be explained by selective mineralization of $\mathrm{Mn}$ or Fe, resulting in differences in the chemical composition of trachelomonad envelopes, as suggested by some authors (Leedale 1975; Dunlap \& Walne 1985). Heinrich et al. (1987) suggested that the chemical composition of Trachelomonas envelopes is species-specific to some extent. They analyzed trachelomonads (T. lefevrei, T. volvocina, T. hispida, T. volvocinopsis) from natural sites. Specimens from the same water sample (e.g., T. lefevrei) varied significantly: some had iron dominant and small amounts of manganese, and others had manganese dominant and only traces of iron. Others (T. volvocina, T. hispida) accumulated only iron. Dunlap et al. (1986) reported no significant difference in the chemical composition of the envelopes they studied: both Strombomonas conspersa $(\mathrm{Pa}-$ scher) Tell \& Conforti and some Trachelomonas species (T. lefevrei, T. hispida var. coronata, $T$. zorensis Deflandre) had manganese as the predominant element; all the loricae had needle-like structures and had dark, mineralized envelopes.

There is little information on $\mathrm{P}$ as the main component of trachelomonad loricae. I found high concentrations of phosphorous in T. manginii. In some Trachelomonas species, Pereira et al. (2003) detected phosphorus accompanied by sulphur, potassium and calcium, with iron dominant. In other work, phosphorus occurred in small or very small amounts in the lorica of $T$. hispida var. coronata and T. lefevrei, and never as the main component (West 1977; Dunlap et al. 1983; Pereira et al. 2003). Donnelly (1979) found large amounts of Fe, $\mathrm{P}$ and $\mathrm{Cl}$ in T. bulla $\mathrm{F}$. Stein.

Such a chemical composition is not limited to species that form loricae. Lepocinclis spyrogyroides B. Marin \& Melkonian (formerly Euglena spirogyra Ehrenb.) showed a chemical composition similar to that of Trachelomonas envelopes 
- warts of L. spirogyroides covering the pellicle in longitudinal rows were composed mainly of $\mathrm{Fe}$ and $\mathrm{P}$, suggested to occur as a complex - iron phosphate (Dawson et al. 1988). Similar mechanisms of ion accumulation have been reported in other species that produce mineralized structures, such as Lepocinclis fusca (G. A. Klebs) Kosmala \& Zakryś [formerly Euglena fusca (G. A. Klebs) Lemmerm.], Lepocinclis spinosa M. S. Bennett \& Triemer (formerly Phacus horridus Pochm.) and Lepocinclis ovum (Ehrenb.) Lemmerm. (Pereira \& Azeiteiro 2003).

Although representatives of the genus $\mathrm{Co}$ lacium Ehrenb. do not produce loricae, warts or spines, they often form gelatinous stalks and cushion holdfasts which facilitate their attachment to substrate. C. vesiculosum Ehrenb. stalks sometimes have characteristic dark brown Fe and Mn deposits which stiffen their surface and turn them brown, but deposition of that material is not an obligatory part of their normal metabolism (Rosowski \& Kugrens 1973; Rosowski \& Willey 1977). In cultured Colacium, Rosowski and Kugrens (1973) showed the role of Fe and Mn compounds in cell growth and stalk production. The organisms developed well and formed stalks in Fe- and Mn-enriched medium. Martin (1970) suggested that $\mathrm{Fe}$ and $\mathrm{Mn}$ compounds contained in copepod skeletons play a role in the stalk development of Colacium that settle on them. The same was suggested by Wołowski et al. (2015), who observed the growth and development of Colacium minimum Fott \& Komárek on Trachelomonas and Strombomonas loricae, which are known to contain iron and manganese, though not always. Similar mechanisms of mineral salts uptake and mineralization may operate in organisms that build iron-enriched external structures. What is obvious is that species that differ from each other in their pellicle ornamentation - warts, spines or other formations - also differ in their chemical composition to some extent. There have been attempts to explain the problem of wall chemical composition in Trachelomonas, especially in taxa with smooth loricae, but no comprehensive hypothesis has emerged.

Some authors have shown or suggested that the color of loricae resulted from their chemical composition, especially from high levels of manganese (Dunlap et al. 1983; Dawson et al. 1988; Wołowski \& Hindák 2005). I did not find a clear connection between lorica color (hyaline, yellow, dark) and element composition; the samples included both light (e.g., T. dubia, T. curta, T. lacustris) and dark (e.g., T. caudata, T. volvocinopsis) loricae, but EDS analyses did not detect Mn in any of them. None of the studied loricae were black. At most they were brown or reddish brown. According to Dawson et al. (1988), low concentrations of $\mathrm{Mn}$ in Lepocinclis spirogyroides can be masked by Fe and detected only occasionally. Dunlap et al. (1983) observed dark golden to brown loricae in Trachelomonas which were Mn-enriched and had dense needle-like structures, as well as hyaline to light golden ones which were Fe-enriched and had granular structure. Dunlap and Walne (1987) showed that an increase in Fe or $\mathrm{Mn}$ in the environment led to modification of the microarchitecture of loricae in Trachelomonas lefe$v r e i$, seen as an increase of granular or needle-like crystalline formations, but other work of theirs (Donnelly \& Walne 1979) found no clear correlation between the color and chemical composition of loricae treated with additional $\mathrm{Fe}$ or $\mathrm{Mn}$, nor any effect on envelope microarchitecture or color. In Trachelomonas hispida var. coronata cultured in iron-enriched standard medium, West and Walne (1980) observed specimens with colorless as well as dark-colored loricae, both spiny and smooth. In material from freshwaters of Argentina and Brazil, Conforti et al. (1994) found no relationship between the dark color of trachelomonad loricae and their element composition, which lacked Mn. Wang et al. (2003) reached the same conclusion in a comparison of the color and chemical composition of Strombomonas and Trachelomonas loricae from waterbodies in northeastern China; those specimens mainly showed high $\mathrm{Si}$ and $\mathrm{Fe}$ content and a lack of Mn.

It is difficult to pinpoint one well-defined pattern of lorica chemistry. The presence of Fe in loricae wall structure is clear, but other elements occur irregularly (Mn and other ions) and seem to be strongly influenced by environmental factors. Van Veen et al. (1978) demonstrated the 
role of $\mathrm{pH}$ in $\mathrm{Fe}$ oxidation processes in bacteria. Work by Dunlap and Walne (1985) showed that Fe accumulation is efficient under high $\mathrm{NH}_{4} \mathrm{OH}$ in the culture medium, which was associated with increased medium/water $\mathrm{pH}$; they also stressed the importance of physiological conditions such as cellular activity, the types of mucilage and mucopolysaccharides produced by a cell, and the presence of enzymes required to convert inorganic forms to organic ones. My results point to the need for further analyses of the chemical composition of trachelomonad loricae and the effects of a host of environmental and physiological conditions on the uptake of minerals.

Acknowledgements. I thank Associate Professor Emilia Fornal (EMF Lab Emilia Fornal, Lublin, Poland) for help in understanding the details of data charts, Anna Latkiewicz (Laboratory of Field Emission Scanning Electron Microscopy and Microanalysis, Jagiellonian University, Kraków, Poland) for assistance with EDS analyses, Emil Zięba (Laboratory of Confocal and Electron Microscopy, Centre of Interdisciplinary Research, John Paul II Catholic University of Lublin, Poland) for very fruitful discussions of the intricacies of SEM/EDS analyses, and three anonymous reviewers for helpful remarks and suggestions on the manuscript. This work was supported by the Polish Ministry of Science and Higher Education (grant no. 2P04C 043 30) and the W. Szafer Institute of Botany of the Polish Academy of Sciences through its statutory funds.

\section{REFERENCES}

Barnes L. S. D., Walne P. L. \& Dunlap J. R. 1986. Cytological and taxonomic studies of the Euglenales. I. Ultrastructure and envelope elemental composition in Trachelomonas. Brit. Phycol. J. 21: 387-397.

Bowler C., Van Camp W., Van Montagu M. \& Inze D. 1994. Superoxide dismutase in plants. Crit. Rev. Pl. Sci. 13: 199-218.

Bozzola J. J. \& Russell L. D. 1995. Electron microscopy. Principles and techniques for biologists. Jones and Bartlett, Boston - London.

Brosnan S., Brown P. J., Farmer M. A. \& Triemer R. E. 2005. Morphological separation of the euglenoid genera Trachelomonas and Strombomonas based on lorica development and posterior strip reduction. J. Phycol. 41: 590-605.

Büchel C., Barber J., Ananyev G., Eshaghi S., Watt R.
\& Dismukes C. 1999. Photoassembly of the manganese cluster and oxygen evolution from monomeric and dimeric CP-47-reaction center photosystem II complexes. Proc. Natl. Acad. Sci. U.S.A. 96: 14288-14293.

Conforti V., Walne P. L. \& Dunlap J. R. 1994. Comparative ultrastructure and elemental composition of envelopes of Trachelomonas and Strombomonas (Euglenophyta). Acta Protozoologica 33: 71-78.

Dawson N. S., DunlaP J. R. \& Walne P. L. 1988. Structure and elemental composition of pellicular warts of Euglena spirogyra (Euglenophyceae). Brit. Phycol. J. 23: 61-69.

Deflandre G. 1930. Strombomonas, nouveau genre d'Euglénacées. Arch. Protistenk. 69: 551-614.

Dillard G. E. 2000. Freshwater algae of the Southeastern United States. Part 7: Pigmented Euglenophyceae. Biblioth. Phycol. 106: 1-176.

DonNelly L. S. 1979. Comparative cellular ultrastructure and chemical characterization of envelopes of three species of Trachelomonas (Euglenophyta). Ph.D. Dissertation, University of Tennessee, Knoxville.

Donnelly L. S \& Walne P. L. 1979. Comparative ultrastructure of three species of Trachelomonas (Euglenophyceae). A.S.B. Bull. 26: 46.

DuAngJan K. \& Wolowski K. 2013. New taxa of loricate euglenoids Strombomonas and Trachelomonas from Thailand. Polish Bot. J. 58: 337-345.

DunlaP J. R. \& Walne P. L. 1985. Fine structure and biomineralization of the mucilage in envelopes of Trachelomonas lefevrei (Euglenophyceae). J. Protozool. 32: 437-441.

DunlaP J. R. \& Walne P. L. 1987. Variations in envelope morphology and mineralization in Trachelomonas lefevrei (Euglenophyceae). J. Phycol. 23: 556-564.

Dunlap J. R., Walne P. L. \& Bentley J. 1983. Microarchitecture and elemental spatial segregation of envelopes of Trachelomonas lefevrei (Euglenophyceae). Protoplasma 117: 97-106.

Dunlap J. R., Walne P. L. \& Kivic P. A. 1986. Cytological and taxonomic studies of the Euglenales. II. Comparative microarchitecture and cytochemistry of envelopes of Strombomonas and Trachelomonas. Brit. Phycol. J. 21: 399-405.

EhrenBerG C. G. 1833. Dritter Beitrag zur Erkenntnis grosser Organisation in der Richtung des kleinsten Raumes. Abh. Königl. Akad. Wiss. Berlin 1833: 145-336.

Ferroni L., Baldisserotto C., Fasulo M. P., Pagnoni A. $\&$ Pancaldi S. 2004. Adaptive modifications of the photosynthetic apparatus in Euglena gracilis Klebs exposed to manganese excess. Protoplasma 224: 167-177.

Heinrich G., Kies L. \& SChröder W. 1987. Untersuchungen über die Mineralisierung der Gehause von Trachelomonas-Arten (Euglenophyceen) mit Hilfe des Laser-Mikrosonden-Massenanalysators LAMMA 500. Phyton (Horn) 26: 219-225. 
LEEDALE G. 1975. Envelope formation and structure in the euglenoid genus Trachelomonas. Brit. Phycol. J. 10: 17-41.

Mann H. \& Fyfe W. S. 1988. Biogeochemical cycling of the elements in some fresh water algae from gold and uranium mining districts. Biorecovery 1: 3-26.

Martin J. H. 1970. The possible transport of trace metals via moulted copepod exoskeletons. Limnol. Oceanogr. 15(5): 756-761.

Pereira M. J. \& Azeiteiro U. M. M. 2003. Structure, organization and elemental composition of the envelopes of Trachelomonas (Euglenophyta): a review. Acta Oecologica 24: 57-66.

Pereira M. J., Azeiteiro U. M. M., Gonçalves F. \& Soares A. M. V. M. 2003. Inorganic composition of the envelopes of Trachelomonas Ehr. (Euglenophyta). Acta Oecologica 24(Suppl. 1): 317-324.

Pla S. 2001. Chrysophycean cysts from the Pyrenees. Biblioth. Phycol. 109: 1-179.

Poniewozik M. 2015. Variations in trachelomonad envelope morphology as a response to environmental conditions. In: T. Noga \& J. StaneK-TARKowsKa (eds), Algae as indicators of environmental changes, p. 83. Book of abstracts, $34^{\text {th }}$ Internaional Conference of the Polish Phycological Society, Rzeszów - Polańczyk, 18-21 May 2015.

PoniewozIK M. 2016. The euglenoid genus Trachelomonas (Euglenophyta) from eastern Poland. Study on morphology and ultrastructure of envelopes with comments on morphologically similar species. Phytotaxa 278(3): 181-211.

Preisig H. R. 1994. Siliceous structures and silicification in flagellated protists. Protoplasma 181: 29-42.

Richardson L. L., Aguilar C. \& Nealson K. H. 1988. Manganese oxidation in $\mathrm{pH}$ and $\mathrm{O}_{2}$ microenvironments produced by phytoplankton. Limnol. Oceanogr. 33: 352-363.

Rosowski J. R. \& Kugrens P. 1973. Observations on the euglenoid Colacium with special reference to the formation and morphology of attachment material. J. Phycol. 9(4): $370-383$.

Rosowski J. R. \& WiLley R. L. 1977. Development of mucilaginous surfaces in euglenoids. I. Stalk morphology of Colacium mucronatum. J. Phycol. 13(1): 16-21.

Starmach K. 1983. Euglenophyta - Eugleniny. Flora Słodkowodna Polski. 3. Państwowe Wydawnictwo Naukowe, Warszawa - Kraków.

Steinberg C. \& Klee R. 1984. Zur chemie von Trachelomonas-loricae. Arch. Protistenk. 128: 238-294.
Sunda W. G. \& Huntsman S. A. 1986. Relationships among growth rate, cellular manganese and manganese transport kinetics in estuarine and oceanic species of the diatom Thalassirosira. J. Phycol. 22: 259-270.

Van Veen W. L., Mulder E. G. \& Deinema M. H. 1978. The Sphaerotilus-Leptothrix group of bacteria. Microbiol. Rev. 42: 329-356.

WANG Q.-X., LiU H.-J. \& Zhang D.-W. 2000. Fine structure and elemental composition of envelopes of Trachelomonas scabra var. ovata Playf. Acta Hydrobiol. Sinica 24(6): 669-671 (in Chinese).

WANG Q.-X. LiU H.-J., Yu J., SUN S.-Q., ZHANG D.-W. \& BAO W.-M. 2003. Comparative studies on the fine structure and elemental composition of envelopes of Trachelomonas and Strombomonas (Euglenophyta). Acta Bot. Sinica 45(5): 601-607.

WeSt L. K. 1977. Cellular organization and biomineralization of the envelope of Trachelomonas hispida var. coronata. Ph.D. Thesis, The University of Tennessee, Knoxville.

West L. K. \& Walne P. L. 1980. Trachelomonas hispida var. coronata (Euglenophyceae). II. Envelope substructure. J. Phycol. 16: 498-506.

West L. K., Walne P. L. \& Bentley J. 1980. Trachelomonas hispida var. coronata (Euglenophyceae). III. Envelope elemental composition and mineralization. J. Phycol. 16: 582-591.

Wolowski K. 2005. Taxonomic comments on seven Trachelomonas taxa (Euglenophyceae). Biologia (Bratislava) 60: 343-347.

Wolowski K. \& Hindák F. 2004. Taxonomic and ultrastructural studies of Trachelomonas Ehrenberg emend. Deflandre (Euglenophyta) from Slovakia. Nova Hedwigia 78: 179-207.

Wolowski K. \& HindáK F. 2005. Atlas of Euglenophytes. VEDA Publishing House, Slovak Academy of Sciences, Bratislava.

Wolowski K. \& Walne P. L. 2007. Strombomonas and Trachelomonas species (Euglenophyta) from south-eastern USA. Eur. J. Phycol. 42: 411-433.

Wolowski K., Duanguan K. \& Peerapornpisal Y. 2015. Colacium minimum (Euglenophyta), a new epiphytic species for Asia. Pol. Bot. J. 60(2): 179-185.

Wolowski K., PoniewoziK M. \& Juráñ J. 2016. Morphological variability of loricae in Trachelomonas caudata complex (Euglenophyta). Cryptog. Algol. 37: 97-108. 